is, however, quite in keeping with the ordinary first attempts to obtain some knowledge of the stocking in the tropical forest. The suggested classification of durability and impregnation susceptibility appear to be somewhat clumsy and capable of simplification. A summary of the uses of local timbers is given. The little monograph should prove of use both to forest officer and timber buyer; and may even ensure some measure of control over the all too common unsupervised fellings in tropical forests, which have been taking place on an increased scale.

\section{The Imperial Forestry Institute}

In the seventeenth annual report, for 1940-41, of the Imperial Forestry Institute (Oxford, The Holywell Press, Ltd., 1941) it is stated that the year was the first under the new organization, one result of which is to amalgamate the Oxford School of Forestry with the Institute. The interruptions of leave and so forth naturally interfered with Colonial forest officers taking refresher courses at the Institute. As has been the case with other forestry schools, practical forestry courses had to be confined to Great Britain. The professor of forestry, Prof. H. G. Champion, was fortunate in being able to retain a certain staff at the Institute. As a consequence some degree of investigation and experimental research work was continued in sylviculture, mensuration and management, soil science (in which the valuable co-operation of Dr. M. C. Rayner of Bedford College, London, was afforded), tropical forest botany and fruit pathology.

\section{Economy of Tin in Bearings}

SINCE the change to Japanese control of the tinproducing regions in south-eastern Asia, the sources of about two-thirds of their supplies have been lost to the Allies. In an attempt to make this good, the Ministry of Supply has just issued a pamphlet on modifications recommended in bearing-metal practice. More than 2,000 tons of tin are used annually in Great Britain in bearing-metals, and the new suggestions, if loyally adopted, would, it is estimated, ensure a saving of 65 per cent, equal to the entire output of the Cornish mines last year. This pamphlet is available from the Non-Ferrous Metals Control, Grand Hotel, Rugby, or the Tin Research Institute, Fraser Road, Greenford, Middlesex. The white bearing-metals have been divided into four groups with $80-92,68-75,7-12$ and $0-5$ per cent of tin respectively. Alloys with 12-68 per cent of tin have very rightly been omitted entirely, as suitable alloys for practically any purpose can be found in the compositions still retained, modified, if necessary, by other additions. A long list of typical bearings is given with the class of alloy suitable for each. Alloys falling outside these groups may be used only with the approval of the Non-Ferrous Metals Control.

A further appreciable saving may be made by reducing the thickness of white metal linings, a practice which has been steadily growing for some years. As a result, especially in the automobile industry, it has been found that the thinner linings can often carry heavier loads with an increased factor of safety. Other suggestions for economy include careful segregation and collection of scrap, the use of steel bushes lined with bronze instead of solid bronze ones, and the substitution, for most purposes, of an alloy containing 85 copper, 5 tin, 5 lead, and 5 zinc for Admiralty gunmetal.

\section{The U.S. National Academy and Calendar Reform}

A PoLl of the U.S. National Academy of Sciences indicates a three-to-one preponderance of opinion in favour of a calendar reform which would 'even up' the lengths of the months, giving each twenty-six working days and having each month begin on a Sunday. The ballot was conducted by Prof. W. E. Castle, of the University of California, Berkeley. He received responses from 168 of them, or more than half the membership of the Academy. Of those answering, 76 per cent favoured the change, 10 per cent opposed, and 14 per cent were undecided. Of those who favoured the change, 58 per cent wanted it initiated in 1945 , which is the next year that begins on a Sunday ; 42 per cent were against this unless the War ends soon enough.

\section{Earthquakes in the Pacific}

The United States Coast and Geodetic Survey, in co-operation with Science Service and the Jesuit Seismological Association has found the epicentres of two recent earthquakes. The first, on March 1, 1942, took place at $9 \mathrm{~h} .52 \cdot 0 \mathrm{~m}$. U.T. The tentative epicentre, calculated from instrumental recordings at eight observatories, was latitude $13^{\circ} \mathrm{N}$., longitude $91^{\circ} \mathrm{W}$., which is in the Pacific Ocean, south of San José in Guatemala (Central America).

The second shock, on March 5, 1942, at $19 \mathrm{~h}$. $48 \cdot 2 \mathrm{~m}$. U.T., had its provisional epicentre at latitude $48^{\circ} \mathrm{S}$., longitude $98^{\circ} \mathrm{W}$., which is in the Pacific Ocean to the west of southern Chile. The focus of this latter shock is estimated to have been at a depth of some 250-300 km., so that it might be termed an 'intermediate' shock. Earthquake shocks have been known to occur down to depths of $700 \mathrm{~km}$. Both the above earthquakes occurred in regions known to be liable to earthquakes.

\section{Demographic Census of Rio de Janeiro}

The last census of Brazil showed that on September 1, 1940, Rio de Janeiro had 1,781,567 inhabitants (J.Amer. Med. Assoc., Feb. 14). The decline of births was illustrated by the fact that whereas in the period 1921-1930 the births numbered 344,921, in the period 1931-1940 only 321,976 births were registered, although there was an increase in the population. In the first period there were 248,964 deaths, and in the second period 274,233. This increase, however, was not in proportion to the growth of the population. In the same periods the marriages numbered 80,545 and 106,112 respectively, though there was a decrease in the birth-rate. The population of the capitals of the Brazilian States was $5,661,091$ in 1940 , or $13 \cdot 6$ per cent of the population of the whole country. In 1920 the figure was only $8 \cdot 6$ per cent of the whole nation.

\section{Institute of Fuel : Melchett Medallist}

The Melchett Medal for 1942 of the Institute of Fuel has been awarded to Dr. Arno Carl Fieldner, the head of the Technologic Branch of the Bureau of Mines, Washington, for outstanding work carried out by him and under his supervision in connexion with fuel. The Melchett Medal was founded in 1930 by the first Lord Melchett, and has been presented to seven Englishmen, one American, one Frenchman, and three Germans. 